\title{
Should Uber drivers be considered employees for South African income tax purposes?
}

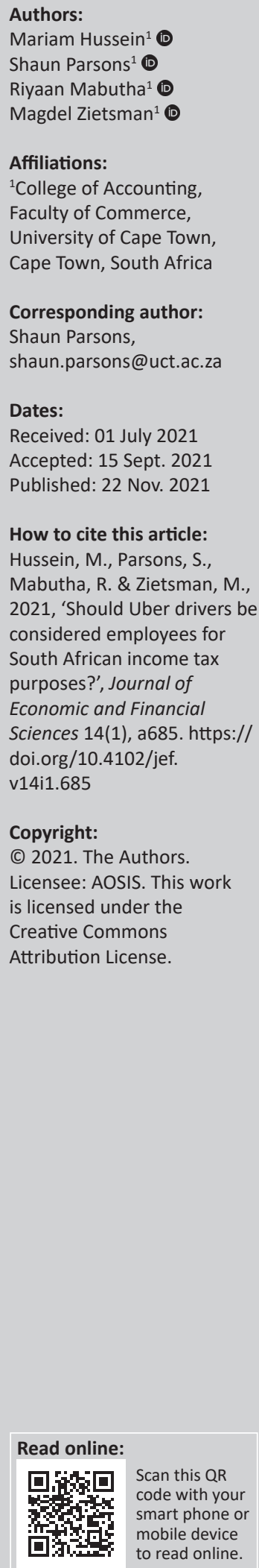

Orientation: Uber is a leader in the gig economy both internationally and in South Africa. One of the key elements of Uber's business model is that drivers operate as independent contractors rather than employees. Whilst this may reduce costs, it may also negatively affect tax collection.

Research purpose: This study considers whether Uber drivers should be classified as employees or independent contractors in South Africa for employees' tax purposes.

Motivation for the study: As the gig economy expands, uncertainty exists as to how traditional approaches to taxation apply and the extent to which they remain appropriate to new business models that have non-traditional relationships with their participants. This is evident by the extent of disputes arising internationally, and particularly in the United States of America (USA), where Uber was founded.

Research approach/design and method: This study engages in comparative legal research to determine the extent to which attempts to resolve this question in the USA may inform the South African context.

Main findings: The lack of consistent classification outcomes in the USA suggests that it may be difficult to reach a conclusive classification of Uber drivers in South Africa for employees' tax purposes using the current tests. Whilst these tests may be adapted, this study supports calls for rethinking the link between tax collection and traditional employment relationships.

Contribution/value-add: This study contributes to the development and interpretation of South African tax legislation in the context of new technologies and business models, and provides recommendations for rethinking the approach to tax collection in these contexts.

Keywords: employee; employees' tax; gig economy; independent contractor; taxation; Uber.

\section{Introduction}

The 'gig economy' refers to a free-market system of independent contractors completing specific tasks or projects, rather than seeking full-time employment (KPMG in Saudi Arabia 2020). The gig economy is estimated to contribute $\$ 1$ trillion annually to the economy of the United States of America (US/USA) with 57 million Americans engaging in either full- or part-time gig work (Henderson 2020). It is estimated that more than 50\% of the US workforce will consist of freelance workers by 2023 (MBO Partners 2019). The flexibility offered by the gig economy remains fundamental to its growth, as the gig worker is in control of when, where and how work is performed (Manyika et al. 2016).

Governments require tax revenue to foster economic growth, to develop health and education services and to build infrastructure to ensure a prosperous and functional society (World Bank Group 2019). Responsibility for withholding payroll taxes resides with the employer (Murray 2021). Tax is however not withheld from payments made to independent contractors (Internal Revenue Service 2021e; South African Revenue Service 2019). The absence of traditional employment relationships within the gig economy emphasises both the relevance and complexity of worker classification.

The definition of an employee can be found in both the South African Income Tax Act No. 58 of 1962 and the U.S. Labour Relations Act of 1935. There is however no definition of an independent contractor in either legislation. Instead, both statutory and common law tests are applied to the relevant facts to determine a worker's status. These tests are subjective, and consequently may result in divergent outcomes. 
Traditional taxi drivers are employees and most trips are either booked through a call centre or by waving down a taxi (Goodin \& Shaw 2017; Hall-Geisler 2014). Uber, however, classifies its drivers as independent contractors, whilst communication is facilitated exclusively through the Uber application (Reis \& Chand 2020).

\section{Research purpose and objectives}

The purpose of this research is to determine whether Uber may have a duty as 'employer' to withhold employees' tax from amounts paid to drivers and to remit amounts withheld to the South African Revenue Service (SARS). If such a duty exists, the failure to do so may result in the imposition of penalties and interest (Income Tax Act 1962).

The objective of the article is therefore to establish whether Uber drivers should be classified as 'employees' as defined in the Income Tax Act No. 58 of 1962 of South Africa, as informed by Interpretation Note 17 of SARS and to provide recommendations that will support tax collection in the context of the gig economy.

\section{Literature review}

\section{Uber and the role of the gig economy}

Uber provides a smartphone application to connect drivers and riders (Uber 2021b), offering greater transparency, lower prices, and a faster service than traditional transport providers (Pepić 2018). The passenger is charged according to time and distance driven. Uber receives a service fee (of $25 \%$ ) and the balance is transferred to the driver's account (Helling 2021). Drivers are required to have a vehicle that meets Uber's requirements, a valid driver's license and the Uber application on their smartphones (Uber 2021c). Drivers are free to work when and where they choose (Brown 2016). Uber classifies its drivers as independent contractors based on the premise that it is a technology and not a transportation company (Marshall 2019). Uber views itself as a third party, supplying a platform for drivers and passengers to connect (Hasner 2019).

Founded in 2009 and launched in the following year, Uber experienced rapid growth in the US (Iqbal 2021) and held $67 \%$ of the US market in March 2021 (Wong 2021). Uber was launched in South Africa late in 2013 (Wilson 2013) where it has disrupted the business model of the incumbent metered taxi industry, whilst facing objections to its legality similar to those raised in other countries (Dube 2015).

\section{The importance of worker classification}

The classification of Uber's drivers has been a contentious issue (Abboud \& Wagstaff 2015; Reis \& Chand 2020). In 2015, Uber had been involved in a little over 50 lawsuits in the US alone (Brown 2016), with one of the major lawsuits resulting in a $\$ 100$ million settlement in which Uber conceded that it had misclassified its drivers as independent contractors in California and Massachusetts (Department for Professional
Employees 2016; Liss-Riordan \& Pagano 2015). The controversy over Uber drivers' employment status continues within several different states. California's government has approved Assembly Bill 5, which creates a more stringent test to distinctly designate Uber drivers as employees (as opposed to independent contractors) (Marshall 2019; Reis \& Chand 2020). Uber has however successfully defended the classification of its drivers as independent contractors in the states of Pennsylvania and Florida (Reis \& Chand 2020).

Uber's refusal to classify drivers as employees is mainly profit-driven (Efrati 2019). Employees are afforded more rights than independent contractors. Both in South Africa and the US, employees are protected by numerous employment laws, entitling them to compensation for and regulation of overtime, minimum wages, and unemployment insurance fund benefits (Basic Conditions of Employment Act 1997; National Minimum Wage Act 2018; Unemployment Insurance Act 2001; U.S. Department of Labor 2019, 2021). In the US, these costs usually make up $40 \%$ of a business's payroll expense (Department for Professional Employees 2016). Uber's classification of drivers as independent contractors is central to its lower pricing structure, ensuring a competitive advantage over traditional taxi operators (Edelman \& Geradin 2015). It is estimated that Uber would incur a 20\% increase in cost worldwide if drivers are classified as employees (Efrati 2019).

The classification of Uber drivers not only affects their treatment in terms of labour laws but also has far-reaching tax consequences. Uber need not withhold any taxes from drivers if they are independent contractors. Drivers are responsible for registering with tax authorities and paying any taxes due (Means \& Seiner 2015). This in turn increases the risk of individual non-compliance and the burden on tax collection authorities.

\section{Research design}

\section{Research approach}

This study in taxation falls within the legal research paradigm. This paradigm is distinguished from positivism and interpretivism by the application of a normative framework in conducting analysis and drawing conclusions. In varying contexts, this normative framework may be represented either by the legislation itself or by a broader set of governing principles upon which legislation is developed (Taekema 2018).

Within legal research, this study may be classified as doctrinal research. Doctrinal research is 'centred on the reading and analysis of the primary sources of legal doctrine' (Hutchinson \& Duncan 2012), and aims to answer questions 'in law' rather than 'about law' (McKerchar 2008). The study is supported through the use of comparative legal research, in which the legal doctrine of the jurisdiction in question is compared and contrasted with that of another jurisdiction (Hutchinson 2015). 


\section{Research method}

This study analyses the novel concept of ride-sharing services within the newly emerging gig economy and attempts to interpret the income tax consequences thereof within the framework of South African income tax legislation and supporting guidance.

The appropriate classification of Uber drivers within the context of the US is considered, both by comparing the guidance outlined in the Employer's Supplemental Tax Guide (Publication 15-A) with that of South Africa (SARS Interpretation Note 17) and by exploring the perspectives of the US courts in contrasting judgements and considering the bases thereof. The US was used as a basis for comparison as it is the country of Uber's origin and because of the prominence of legal disputes involving the classification of Uber drivers in the US.

The study proceeds as follows. The next section considers the prevalent tests applied in the US in determining employee status and presents two recent US cases involving Uber driver classification with contrasting outcomes. Thereafter, the study considers the application of the South African statutory and common law tests of employee status to Uber drivers, informed by comparable tests in the US. The study concludes by highlighting the difficulties that may arise in attempting to conclusively determine the employee status of Uber drivers for tax purposesinSouth Africa, and presents recommendations.

\section{Part I: Employees in the United States of America \\ Determination of employee status in the United States of America}

Control is the focal point of the definition of 'employee' in Title 42 of the United States Code. Independent contractor status is established by ruling out that one is an employee (Bales \& Woo 2016). A worker that is subject to control over the way work is to be performed is an employee, whereas control over only the result points to an independent contractor (Internal Revenue Service 2021d).

\section{Tests to establish worker status}

There is no statutory test for determining worker status in the US. Rather, the IRS applies the Control Test - a codified version of the common law - to determine worker status (Bales \& Woo 2016). In addition, the US courts have over the years developed several tests, which aid in reaching conclusions regarding worker classification disputes. The two most prevalent of these tests are the $\mathrm{ABC}$ Test and the Economic Realities Test (Sondermann Capizzi 2019). These three tests are discussed here.

\section{The control test}

The determination of whether control exists is the key factor in this test in determining classification. The test is divided into three categories: behavioural control, financial control and type of relationship (IRS 2021d). There is no formula or set number of factors to determine the outcome; the various factors in all three categories should be weighed subjectively to arrive at a conclusion (IRS 2021e).

Behavioural control: This category analyses whether the business has the right to control the work, regardless of whether this right is exercised. It is further divided into four subcategories:

1. Type of instructions given: This could include where the workers need to obtain supplies from and who can or cannot assist them, the type of equipment they should use, and when, where and in what sequence work is to be performed (IRS 2021c).

Uber drivers must use vehicles that comply with Uber's requirements and third parties cannot be contracted to complete a trip booked with a specific driver. Whilst these indicate control by Uber, there are no prescriptions regarding when, where and the sequence in which work is to be performed or the brand of vehicle that must be used.

2. Degree of instruction: This test assesses the extent of detail provided to instruct the worker. Greater detail is indicative of employee status. The test can, however, affirm employee status even in the absence of any instructions. The fundamental consideration is whether the business has the right to control the detail of work performed or whether this right has been forfeited (IRS 2021c).

As observed in (1), Uber does not instruct drivers when and where, or for how long, to offer their services. Uber does, however, provide training videos on how to improve the quality of service provided by drivers. Whilst Uber states that these videos are voluntary to improve the number of rides based on improved ratings, drivers may be penalised and ultimately removed from the platform for having a low rating. That Uber indirectly controls the details of rides through the star rating system, may suggest employee classification.

3. Evaluation system: A system measuring the details of how the work is performed points towards employee status, whereas a system measuring the result only can point to either classification (IRS 2021c).

Whilst Uber does not directly evaluate drivers, the Uber application has several criteria on which a driver is rated by customers, ranging from driver-passenger interaction to the choice of route and how tidy the car was. The evaluation therefore focuses not only on the result, but also on the customer experience. The presence of such a rating system may be suggestive of an employment relationship.

4. Training: Independent contractors are at liberty to use their own methods to achieve a result. Training provided indicates the business' preference for doing work in a specific manner (IRS 2021c). 
As observed in (2), Uber provides voluntary training videos to drivers on how to improve their customer experience, which is monitored through customer ratings. By controlling the details of each trip using a detailed rating system and by requiring drivers to maintain a minimum rating to remain active on the application, Uber is in essence dictating method, which may point towards employee classification.

The application of the behavioural control category is summarised in Table 1. This category would seem to point towards employee classification.

Financial control: Financial control considers the extent to which economic control is exercised by the business. Five subcategories offer guidance in establishing whether financial control resides with the business or the worker:

1. Significant investment: The greater the financial investment, the more likely that the worker is an independent contractor (IRS 2021a).

Uber drivers are required to provide their own vehicles complying with Uber's requirements, which is a substantial capital investment. A driver may be provided with a smartphone on which the Uber application can run. The significance of the capital outlay required for a vehicle is suggestive of independent contractor classification.

2. Unreimbursed expenses: Unreimbursed expenses suggest classification as an independent contractor, as employees are generally reimbursed if expenditure is incurred whilst performing work (IRS 2021a). Fixed costs, incurred regardless of whether work is performed, are emphasised by the IRS as an indicator of independent contractor status (Nickolas 2021).

Uber drivers are not reimbursed for expenditure such as fuel, maintenance or depreciation. Interest instalments, if the car is financed, would be fixed, regardless of how productively the driver uses the vehicle. This subcategory therefore favours independent contractor classification.

3. Opportunity for profit or loss: The opportunity for profit or loss indicates that the worker is an independent contractor (IRS 2021a).

Uber drivers' income is determined by when, where and for how long they offer rides. Uber drivers make a capital investment (the vehicle) and are responsible for expenditure incurred to operate their vehicle, meaning that it is possible to incur a loss. Uber, however, sets prices and is responsible for promoting the brand and platform, which directly impacts drivers' opportunity for profit. On

TABLE 1: Application of the behavioural control subcategories.

\begin{tabular}{ll}
\hline Subcategories & Employee or independent contractor \\
\hline 1. Type of instruction & Employee/independent contractor \\
2. Degree of instruction & Employee \\
3. Evaluation system & Employee \\
4. Training & Employee \\
\hline
\end{tabular}

balance this subcategory would seem to favour independent contractor status.

4. Services available to the market: This test assesses the extent to which a worker can seek and pursue business opportunities (IRS 2021a).

Uber drivers may seek out driving opportunities where and when they prefer and may also engage in other income-earning activities, which suggests that they are operating as independent contractors.

5. Method of payment: Employees receive periodic wages or salaries, whether hourly, weekly or monthly. Independent contractors receive a flat fee (IRS 2021a).

Uber drivers receive a fee per trip, depending on the distance and time of day. There is no periodic payment independent of work performed, suggesting independent contractor status.

The application of the financial control category is summarised in Table 2. In contrast to behavioural control, which suggests employee classification, financial control suggests independent contractor status.

Type of relationship: This category analyses the relationship between the parties and whether the contract reflects the true nature of the relationship they intend to form. Four subcategories aid in this assessment:

1. Written contracts: A written contract, indicating either that a worker is an employee or independent contractor, is insufficient if the true nature of relations between the business and worker reflects the opposite (IRS 2021b).

The contract between Uber and its drivers states that the drivers are independent contractors.

2. Employee benefits: Independent contractors are typically not entitled to benefits, such as insurance, pension plans, paid leave and disability insurance. However, the absence of such benefits does not necessarily disqualify a worker from being an employee (IRS 2021b).

Uber does not provide drivers with these benefits. Although not conclusive, this suggests independent contractor status.

3. Permanency of the relationship: Relationships created with the intent by both parties of being indefinite, is indicative of an employer-employee relationship. A relationship that is intended to last for a project or predetermined period suggests that the worker is an independent contractor (IRS 2021b).

The relationship between Uber and its drivers exists on a trip-by-trip basis. However, it could also be said that at

TABLE 2: Application of the financial control subcategories

\begin{tabular}{|c|c|}
\hline Subcategories & Employee or independent contractor \\
\hline 1. Significant investment & Independent contractor \\
\hline 2. Unreimbursed expenditure & Independent contractor \\
\hline 3. Opportunity for profit or loss & Independent contractor \\
\hline 4. Services available to the market & Independent contractor \\
\hline 5. Method of payment & Independent contractor \\
\hline
\end{tabular}


the time of registering with Uber the parties do not have a fixed end point in mind.

4. Services provided as key activities of the business: A worker providing such services is more likely to be subject to the control of a business and therefore an employee (IRS 2021b).

Transport is the essence of Uber's business. Drivers are therefore providing a key service, which is being controlled by means of the rating system, as discussed under behavioural control. Uber drivers are not allowed to delegate or subcontract to a third party.

The application of the type of relationship category may be summarised as presented in Table 3.

Whereas application of the behavioural control considerations suggested employee classification and the financial control considerations leaned towards independent contractor status, the type of relationship does not appear to favour either outcome. Classification as either employee or independent contractor therefore seems possible when applying the Control Test holistically.

\section{The $A B C$ test}

The state of California approved Assembly Bill No. 5 in September 2019, which prescribes the adoption of what has become referred to as the ABC Test, as applied in the case of Dynamex Operations West v. Superior Court of Los Angeles (Worker Status: Employees and Independent Contractors, Assembly Bill 2019). This test has since also been adopted by the states of Illinois, Massachusetts and New Jersey (Sondermann Capizzi 2019). The ABC Test assumes an individual to be an employee, unless all three (A, B and C) of the following factors are proved to be present, in which case the individual will be accepted as an independent contractor (Worker Status: Employees and Independent Contractors, Assembly Bill 2019):

A. The individual is free from the control of the hiring company

B. The individual is performing work that exceeds the scope of the company's core business

C. The individual is actively and independently running his or her own business that is of the same nature as the service that will be provided to the hiring company.

The application of the ABC Test to an Uber driver scenario may therefore yield the interpretation presented in Table 4. As all three factors must be proved to be present, it is submitted that B disqualifies Uber drivers from being independent contractors in terms of this test, as they participate in the core business activity of Uber, being the

TABLE 3: Application of the type of relationship subcategories.

\begin{tabular}{ll}
\hline Subcategories & Employee or independent contractor \\
\hline 1. Written contracts & Independent contractor \\
2. Employee benefits & Independent contractor \\
$\begin{array}{l}\text { 3. Permanency of relationship } \\
\begin{array}{l}\text { 4. Services provided as key activities of the } \\
\text { business }\end{array}\end{array}$ & Employee \\
\hline
\end{tabular}

transportation of people. Uber drivers will therefore probably be seen as employees in terms of this test.

\section{The economic realities test}

This test considers both the issue of control and whether the economic reality is that of dependence on the employer or of an independent business (Bruce 2019). The test hinges on six factors, none of which are individually conclusive (McCabe 2016):

a. The extent to which the services rendered are an integral part of the principal's business

b. The permanency of the relationship

c. The amount of the alleged contractor's investment in facilities and equipment

d. The nature and degree of control by the principal

e. The alleged contractor's opportunities for profit and loss

f. The amount of initiative, judgment, or foresight in open market competition with others required for the success of the claimed independent contractor. (U.S. Department of Labor 2008)

The preceding application of the Control Test has already established that (a) supports employee classification, whilst (c) and (e) suggest independent contractor classification. Factor (b) is inconclusive, whilst (d) can be applied to support either employee or independent contractor classification, depending on whether behavioural or financial control is emphasised. Uber drivers are free to choose where, when and for how long they will drive. Uber drivers are effectively in competition with each other, as well as with taxi drivers. Uber drivers need to judge during which hours and in which areas they can book the most trips and use initiative and foresight to increase availability during peak tourist season or for events. Point (f) therefore also points towards independent contractor status.

The application of the Economic Realities Test is summarised in Table 5.

The Economic Realities Test consequently also falls short of providing a conclusive solution to the worker classification dilemma. Three out of the six factors are indicative of independent contractor status, but it could be argued that more weight should be allocated to (a), (b) and (d), in which case the outcome is less clear.

\section{Recent cases: Evidence of conflicting outcomes}

Uber has been subject to more than 170 lawsuits in the US alone since the launch of its operations in 2010 and as a result the US judiciary system (and case law) has been interrogated

TABLE 4: Application of the ABC Test.

\begin{tabular}{ll}
\hline Factors & Employee or independent contractor \\
\hline $\begin{array}{l}\text { 1. Free from control } \\
\begin{array}{l}\text { 2. Exceeds scope of the company's core } \\
\text { business }\end{array}\end{array}$ & Employee/independent contractor \\
$\begin{array}{l}\text { 3. Actively and independently running own } \\
\text { business }\end{array}$ & Independent contractor \\
\hline
\end{tabular}


TABLE 5: Application of the Economic Realities test.

\begin{tabular}{ll}
\hline Subcategories & Employee or independent contractor \\
\hline 1. Services integral to principal's business & Employee \\
2. Permanency of relationship & Employee/independent contractor \\
3. Investment in facilities and equipment & Independent contractor \\
4. Nature and degree of control & Employee/independent contractor \\
5. Opportunities for profit and loss & Independent contractor \\
6. Initiative, judgement, or foresight required & Independent contractor \\
\hline
\end{tabular}

robustly to ascertain the worker status of Uber drivers (Iqbal 2021; Levin 2016). In applying various tests, the US courts have, however, struggled to agree on a consistent basis for determining worker status. This is illustrated by the contrasting judgements of two recent cases with similar facts. It is submitted that whilst these cases sought to establish worker status in the context of employment benefits rather than tax collection, they are nonetheless instructive.

\section{Barbara Berwick versus Uber Technologies Inc.}

The Uber driver in this California case sought to claim employee status entitling her to reimbursement for expenses. In its argument, Uber relied on the contractual terms, which explicitly stated that the driver was an independent contractor (Barbara Berwick v. Uber Technologies, Inc., No. 1146739 EK 2015).

In reaching its verdict, the court considered a myriad factors, ranging from who the driver is in business for to the party supplying tools, the driver's investment, expertise required, supervision, opportunity for profit and loss, permanency of the relationship, intention of the relationship and execution period of work (Brown 2016).

The court observed that the freedoms afforded to drivers are insignificant compared with the aspects Uber controls. Prerequisites for vehicles, termination of contracts for substandard ratings and enforcing of Uber's marketing strategy were some of the factors considered. The court rejected Uber's argument that the terms were in line with industry standards. The court further held that Uber drivers are not highly skilled and the investment in their vehicle is insufficient to determine that they are in business for themselves (Barbara Berwick v. Uber Technologies, Inc., No. 1146739 EK 2015).

The court therefore found that the title of the contract differed from its substance. Uber's core business, of providing transport, would not be operable in the absence of its drivers. The court disregarded the contract, and the driver was judged to be an employee (Barbara Berwick v. Uber Technologies, Inc., No. 11-46739 EK 2015).

\section{Rasier LLC versus Florida Department of Economic Opportunity}

Rasier LLC, a wholly owned subsidiary of Uber, successfully appealed a ruling that one of its drivers was an employee, entitling him to unemployment insurance after his contract was terminated. Rasier argued that the Berwick decision paid insufficient attention to the signed contract and overemphasised Uber's dependence on its drivers. Uber was compared with an art gallery acting as an agent providing a platform to artists. Drivers are fundamental to Uber's business model but, just as Airbnb hosts are not employees of Airbnb, drivers are not automatically employees of Uber purely because Uber supplies a platform that connects demand (passengers) and supply (drivers) (Rasier, LLC v. Florida Department of Economic Opportunity, No. 00262834 68-02 2015).

The ruling favoured Uber's position that it did not control drivers. It was held that Uber's prescriptions are minimal and that drivers have great autonomy in performing their work. Trips are assigned on distance and not influenced by expertise and appraisals are performed by passengers and not by Uber. The decision referred to past precedent in respect of traditional taxi drivers over whom greater control was exerted yet who were determined to be independent contractors. Citing principles from Keith v. News and Sun Sentinel, 667 So. 2d 167 (Fla. 1995).5, it emphasised the importance of honouring a contract. It found that the explicit nature of the contract established the driver's independent contractor status and Uber's behaviour did not contradict this (Rasier, LLC v. Florida Department of Economic Opportunity, No. 00262834 68-02 2015).

The ruling was subsequently upheld by the Florida District Court of Appeal (Darrin E. McGillis, v. Department of Economic Opportunity; and Rasier LLC, No. 3D15-2758, 2017 WL 438423 2017).

\section{Conclusion - Part I}

In this study attempts to apply the prevalent US tests of employee status to Uber drivers result in inconclusive and potentially contradictory outcomes. The ABC Test appears to favour classification of Uber drivers as employees. Classification under the Control and Economic Realities tests may however be inconclusive, depending on which factors of each test are emphasised. Likewise, consideration of US court cases, albeit in the context of entitlement to employee benefits rather than tax status, further illustrates the lack of a conclusive outcome that might inform the South African position.

\section{Part II: Employees in South Africa South African determination of employment status}

An employee in South Africa is a person other than a company that receives remuneration. Remuneration is any income that is paid to someone in the form of a salary, leave pay, wage, overtime, commission, pension, bonus, gratuity or fee. Remuneration specifically excludes amounts that arise 'in the course of any trade carried on ... independently of the person by whom such amount is paid or payable' (Income Tax Act 1962). The recipient of the latter is commonly referred to as an 'independent contractor', which is another name for a 
small-time subcontractor or an entrepreneur (SARS 2019). In South Africa, the distinction between employee and independent contractor is made using tests that originate from common law and from statute.

\section{Statutory tests}

Theoretically, tests under common law should be applied prior to statutory tests; however, statutory tests are often the starting point in practice, as they enable quicker decisionmaking and involve less subjectivity. The statutory tests can also deem the subject to not be an independent contractor, regardless of the conclusion reached under common law. These tests are however not always applicable. They are narrowly defined and require certain conditions to be present to be conclusive (SARS 2019).

There are two statutory tests considered to be conclusive in the designation of an individual's status for employees' tax purposes. The first test is a negative test, deeming those who meet its criteria not to be independent contractors, whilst the second is a positive test, deeming those who meet its criteria to be independent contractors (SARS 2019).

Although the US does not have a federal statutory test against which comparison may be made (Bales \& Woo 2016), brief consideration may demonstrate that the South African statutory tests do not provide a conclusive result in this context.

The first test consists of two parts. Compliance with both parts of this test will mean that an individual is deemed to not be carrying on a trade independently. The first part focuses on whether a worker performs work and activities mainly on the client's premises. The 'client' can refer to either the recipient of the service or whomever will compensate the worker (Muller 2020).

The nature of Uber's business model means that it fails the first part of this test. Drivers are not confined to a business premises, as they drive passengers around in a service area determined by themselves.

The second part requires that the worker be either supervised or controlled by any person in the way duties are performed. The control aspect of the test looks at whether control is exercised regarding the timing and manner in which work is to be performed (Income Tax Act 1962). Interpretation Note 17 points to other factors indicative of control including prescribing the equipment to use, progress being subject to client approval and providing training to the worker. Supervision could entail the client dictating processes to follow and the exact order in which they are to be completed. Supervision also extends to the client monitoring the pace and productivity of the worker. The presence of either control or supervision is sufficient to satisfy the second part of the first test. In such instances, the individual is deemed to not be an independent contractor, as the client's influence affects the quality and results of the work (SARS 2019).
The presence of supervision or control may be difficult to determine conclusively. Reis and Chand (2020) considered the status of Uber drivers against the indicators of employment relationships contained in the commentary to the OECD Model Tax Convention. They considered Uber's control over driver applications, prices charged, payment processing and consequences imposed against drivers who fail to comply with Uber policies as evidence of an employment relationship. However, they considered flexibility in working hours and location, vehicle ownership, acceptance or rejection of customers, lack of exclusivity and that the major portion of the fare is paid to the driver to suggest an absence of such relationship. In a South African context, such factors may equally suggest both the presence and absence of supervision or control in various respects.

The outcome of the second part of the statutory test may therefore be inconclusive. However, as compliance with both the first part and either of the two elements of the second part of the first statutory test is necessary to deem an individual to not carry on a trade independently, it may be concluded that this test does not preclude Uber drivers from being classified as independent contractors.

The second statutory test deems an individual employing at least three other workers throughout the year of assessment who are not 'connected persons' to that individual to be an independent contractor. The second test overrides both the first test and the common law (SARS 2019).

Uber allows only the registered driver to perform trips. A contravention of this regulation, by employing a third party to complete a trip, will result in an immediate suspension of the driver's account (Uber 2021a). The second test therefore cannot result in an Uber driver being deemed an independent contractor.

As none of the statutory test provides a conclusive determination of an Uber driver's employment status, the common law tests must be analysed.

\section{Common law tests}

The common law tests have been developed by the courts over time and are divided into two categories: the control test and the intuitive tests. They are not as transparent and objective as the statutory test and following a 'checklist' approach is not possible; instead, a dominant impression of the employment relationship should be established (SARS 2019):

1. The control test: This test only looks at one factor, namely control. Control used to be simple to determine, which meant it was the most conclusive criteria. The test focuses on the presence of supervision, the right to control the manner of working and the right to dismiss workers. This test was established because of the vicarious liability doctrine. This doctrine assumes that when a business is liable for damages because of employees' negligence, the 
business can control the employee's work to mitigate this risk (SARS 2019).

As concluded previously, some elements of the relationship between Uber and its drivers indicate the exercise of at least indirect control, whilst others suggest an absence of control. This test is therefore inconclusive:

2. Intuitive tests: As the name suggests these tests require reasoning and intuition. There are four different tests under this category:

a. The 'it's what you think it is' test: This test examines the conclusion that a reasonably informed person with knowledge of the facts would reach (SARS 2019).

Given a superficial understanding of considerations such as vehicle ownership and flexibility, a reasonable person might assume that an Uber driver acts independently. However, the preceding analysis shows that, as further factors are considered, the position becomes less clear.

b. The economic realities test: This test focuses on the economic substance of the relationship. An independent contractor would be able to sustain their business even if the relationship with a specific customer were severed (SARS 2019).

An Uber driver has an immediate economic dependence on Uber. Whilst drivers could continue their activities by joining another similar offering, it could be argued that this is no different from an employee who could find similar employment with another employer. This test might therefore suggest an employment relationship.

c. The organisation test: This test assesses whether the individual and the work performed is fundamental to the business and its activities or merely an accessory to the whole operation. A worker holding a position in the hierarchy of a business is considered an employee (SARS 2019).

Whilst it has been observed previously that Uber drivers perform the core activities of the Uber offering, they do not hold key positions in the hierarchy and no one driver is a scarce resource. This test would therefore suggest independent contractor status.

d. The Dominant Impression Test: This test incorporates features of all the common law tests listed here. The Dominant Impression Test considers an array of indicators to determine the most significant impression a person will have of the relationship. The test originates from the 1970s when in Smit v. Workmen's Compensation Commissioner 1979(1) SA 51(A), the court rejected control as the exclusive evidence of an employment relationship. The test was only sanctioned by the Supreme Court of Appeal in 1996 when it was used in the case of Liberty Life Association of Africa Ltd v. Niselow [1996]17 ILJ 673 (LAC) (SARS 2019).

As the Dominant Impression Test incorporates elements of other tests, which have been considered inconclusive in isolation, and is sanctioned by the
Supreme Court of Appeal, it merits more in-depth consideration.

\section{The dominant impression test}

The objective of the Dominant Impression Test is to determine what is being acquired in a relationship. The acquisition of productive capacity implies that the individual is at the disposal of the business, irrespective of whether there is a task at hand. This is indicative of employee status. In contrast, the acquisition of the result of an individual's productive capacity is indicative of independent contractor status (SARS 2019).

The Dominant Impression Test sets out 22 indicators of what is acquired in a relationship. The indicators are interrelated and not intended to be exhaustive. The relevance of each indicator is to be assessed on an individual basis and not used as a checklist. The significance of these indicators is reflected in their relative weightings: indicators that are nearconclusive, indicators that are persuasive and indicators that are resonant in determining the nature of the relationship. The evaluation should be conducted practically and flexibly and circumstances may dictate which factors are relevant. The test cannot be applied to deduce a score that mandates a particular conclusion (SARS 2019).

Here is a brief explanation of the subcategories. The factors within each subcategory are then considered in Table 6:

1. Near-conclusive indicators (6 of 22).

Indicators in this category are decisive in providing clarification on what is being acquired. The indicators offer insight into how exclusive the relationship is, the quality of control that is present and the financial nature of the relationship (SARS 2019):

\section{Persuasive indicators (4 of 22).}

Persuasive indicators determine whether control in the work environment exists. These indicators consider the degree of the control, establish behavioural control and investigate the rationale behind the acquisition of control. These factors are considered persuasive and not conclusive because control is a necessary but not a sufficient condition for the acquisition of productive capacity (SARS 2019):

3. Resonant indicators (12 of 22).

These indicators create a superficial impression of control and can be subject to manipulation, but still merit consideration. These indicators can be present in the contractual agreement but may give an inaccurate reflection of the actual circumstances (SARS 2019).

\section{Application of the dominant impression test and comparative analysis between South African and US factors}

In attempting to apply this test to Uber drivers, this article will emphasise the near-conclusive indicators of the Dominant Impression Test, as these are considered decisive 
TABLE 6: Application of the Dominant Impression Test.

\begin{tabular}{|c|c|c|}
\hline Dominant Impression Test & Comparable US Control Test subcategories & Employee or independent contractor \\
\hline \multicolumn{3}{|l|}{ Near-conclusive indicators } \\
\hline 1. Control of manner & Degree of instruction & Employee \\
\hline 2. Payment regime & Method of payment & Independent contractor \\
\hline 3. Person who must render the service & $\begin{array}{l}\text { Type of instruction } \\
\text { Services provided as key activities of the business }\end{array}$ & $\begin{array}{l}\text { Employee/Independent contractor } \\
\text { Employee }\end{array}$ \\
\hline 4. Nature of obligation to work & Permanency of relationship & Employee/Independent contractor \\
\hline 5. Employer (client) base & Services available to the market & Independent contractor \\
\hline 6. Risk, profit and loss & Opportunity for profit or loss & Independent contractor \\
\hline \multicolumn{3}{|l|}{ Persuasive indicators } \\
\hline 7. Instructions/Supervision & $\begin{array}{l}\text { Type of instruction } \\
\text { Degree of instruction }\end{array}$ & $\begin{array}{l}\text { Employee/Independent contractor } \\
\text { Employee }\end{array}$ \\
\hline 8. Reports & Evaluation system & Employee \\
\hline 9. Training & Training & Employee \\
\hline 10. Productive time & Type of instruction & Independent contractor * \\
\hline \multicolumn{3}{|l|}{ Resonant indicators } \\
\hline 12. Provision of office & Type of instruction & Independent contractor * \\
\hline 13. Integration/Usual premises & Type of instruction & Independent contractor * \\
\hline 14. Integration/Usual business operations & Services provided as key activities of the business & Employee \\
\hline 15. Integration/Hierarchy and organogram & Services provided as key activities of the business & Independent contractor \\
\hline 16. Duration of relationship & Permanency of relationship & Employee/Independent contractor \\
\hline 17. Threat of termination/ Breach of contract & Evaluation system & Employee \\
\hline 18. Significant investment & Significant investment & Independent contractor \\
\hline 19. Employee benefits & Employee benefits & Independent contractor \\
\hline 20. Bona fide expenses or statutory compliance & Unreimbursed expenditure & Independent contractor \\
\hline 21. Viability on termination & Services available to the market & Independent contractor \\
\hline 22. Industry norms, customs & Written contracts & Independent contractor \\
\hline
\end{tabular}

*, Where the Dominant Impression Test emphasises a specific consideration within the US Control Test equivalent, the outcome has been adjusted accordingly.

in determining whether the worker's productive capacity is acquired. Persuasive and resonant indicators are considered more briefly in Table 6.

It is submitted that the Dominant Impression Test shares substantial similarities with the Control Test in the US. The application of the indicators of the Dominant Impression Test to Uber drivers will therefore be supported by the outcomes of the application of comparable US criteria previously examined.

The near-conclusive indicators in the Dominant Impression Test are as follows:

1. Control of manner: The right to control the different elements of an operation (such as equipment used, raw materials and the appointment of third parties) to ensure a preferred business outcome. The contractual power to control the way a worker's productive capacity is employed is sufficient to indicate employee status, irrespective of whether it is exercised (SARS 2019).

The control of manner test is comparable to the type of instruction and degree of instruction within the US behavioural control test. Here, this study found that the freedom to choose when and where to work was evidence of the absence of control. However, vehicle standards, prohibition of subcontracting trips to third parties, training material, penalties and possible termination for failing to maintain minimum satisfaction ratings were evidence of control and may exert indirect control over those elements suggested as independent.
2. Payment regime: Payment based on effort (or the use of productive capacity) implies that the recipient is an employee, with the opposite being true if payments are results-driven and the manner of completion is not prescribed. Financial sanctions can be applied if a business is dissatisfied with the work of an independent contractor, but a salary reduction when disappointed by an employee's effort is not general practice. Employees are generally paid at regular intervals, irrespective of results achieved, as payment is made for the exclusive use of their service. Independent contractors might receive payment based on time-periods, but material reference will be made to output achieved for that interval (SARS 2019).

Consideration of the payment regime is mirrored in method of payment within the financial control category of the Control Test. Here, this study identified that Uber may impose financial sanctions and ultimately terminate drivers' Uber access. However, payments are based on trips rather than on time worked and are paid by customers. The driver has no obligation of exclusivity to Uber:

3. Person who must render the service: Employment contracts are exclusive; employees are not allowed to transfer their responsibilities to a third party. The contractual right to employ a substitute is indicative of independent contractor status (SARS 2019).

This consideration is relevant to both the type of instruction and services provided as key activities of the business tests, which are subcategories of the behavioural control and type of relationship elements of the Control Test, respectively. In 
considering the application of those tests, it was observed that Uber does not permit drivers to appoint third parties to drive on their behalf and violation can result in immediate suspension of an account. The Uber profile is exclusive to that driver and cannot be transferred.

4. Nature of obligation to work: Employment of a worker on a full-time basis suggests that productive capacity has been acquired, as the worker's services are being provided exclusively to the business. Employment to perform a task or achieve an outcome as opposed to an obligation to be present, irrespective of whether work is available, is indicative of independent contractor status (SARS 2019).

This is reflected in permanency of relationship, which falls within the type of relationship category of the Control Test. There it was observed that the relationship is defined by trip-by-trip performance, although no end date to the relationship is envisaged at inception.

5. Employer (client) base: Independent contractors usually serve several competing businesses in the same industry. Dependence on a single business, exclusivity of productive capacity to a single employer and prohibiting the development of a client base are indicators that the worker is an employee (SARS 2019).

This test is comparable to the services available to the market test, which is a subcategory of financial control. There it was noticed that Uber drivers were not restricted from pursuing other market opportunities.

6. Risk, profit and loss: Exposure to risk indicates economic independence. Like entrepreneurs, independent contractors are exposed to market risks in the industry in which they operate. Independent contractors have the autonomy to make decisions that will have a direct impact on profitability. An employee is not exposed to financial sanctions because of inefficiencies or defective workmanship and their salary is not jeopardised by market risks (SARS 2019).

This test is comparable to the opportunity for profit or loss test, which is a subcategory of financial control. This study noticed that Uber drivers are in control of many decisions that directly affect their income, although these are also affected by the actions of Uber, such as the setting of prices.

The application of the Dominant Impression Test, informed by the preceding analysis of the application of the US Control Test, may be summarised as follows in Table 6 .

\section{South African case law}

Whilst US courts have seen numerous lawsuits on Uber driver classification (Hawkins 2019), South Africa is yet to see its first court case disputing the status of Uber drivers. The Uber model is however similar worldwide and, as the Control Test of the US is largely congruent to South Africa's
Dominant Impression Test, the same ambiguity in judgements may well result.

\section{Conclusion - Part II}

South Africa's Dominant Impression Test incorporates considerations equivalent to all subcategories of the US Control Test. Three of the six near-conclusive indicators of the Dominant Impression Test - (2), (5) and (6) - may lean towards independent contractor classification, although even within these, counter-arguments exist. One factor (1) - suggests employee classification, whilst (3) and (4) are unclear. Consideration of both the persuasive and resonant indicators provides further mixed results. This suggests a less-than-conclusive outcome, which demonstrates the challenge to determining the appropriate classification of Uber drivers for employees' tax purposes in South Africa.

\section{Conclusion and recommendation}

The objective of this article was to compare the classification of Uber drivers as either independent contractors or employees for tax purposes in the US and South Africa by performing an analysis and comparison of the tests applied in these jurisdictions. Although differing in detail, the tests in these jurisdictions share similarities. The lack of conclusive outcomes determined by this study both for US and South African tests highlights the ambiguity between employee and independent contractor status for Uber drivers.

This ambiguity is further evident in the opposing judgements in the cited US cases of Berwick and Rasier LLC. The classification conundrum extends to Europe and Australia. Europe favours employee classification, whereas Australia has categorised Uber drivers as independent contractors (Reis \& Chand 2020). The United Kingdom has taken a firm stance and Uber drivers are deemed to be employees after a Supreme Court ruling in February 2021 upheld a 2016 employment tribunal decision (Naughton 2021). Whilst these cases relate primarily to employee benefits rather than tax classification, they suggest that conclusive tax classification may be similarly problematic.

The lack of conclusive outcomes in attempts in this study and by courts internationally to classify Uber drivers suggests that more widespread ambiguity of classification may be fuelled by rapid changes in technology in the future. Such ambiguity seems inevitable when long-established tests are applied in very different contexts to those in which they were developed. Whilst authoritative clarity on the application of the existing tests would be welcomed, the authors of this study submit that these outcomes may suggest that it is time to reimagine such tests, definitions and even means of tax collection in a way that is consistent with a new context. To this end, Reis and Chand (2020) suggested a hybrid classification. Such a classification would not depend wholly on employment status but would 
recognise that characteristics of both employee and independent contractor status are present and would result in a shared tax burden between the worker and platform provider. Such a solution might promote compliance and ensure efficient collection of taxes, whilst distinguishing tax collection from the other rights and obligations associated with employment status. Whilst amending legislation is a cumbersome process, the gig economy is only likely to further transform the workforce, especially considering layoffs and alternative working arrangements arising from the coronavirus disease 2019 pandemic.

Consideration should also be given to the evolving nature of South African economy. Both impediments to the adoption of new technology and to the collection of taxes will have negative consequences. Legislators should therefore embrace the gig economy and find efficient ways to ensure that gig workers are supported, and ambiguity is eliminated, whilst the tax net must be cast wide enough to achieve an equitable and efficient collection of taxes.

\section{Acknowledgements}

The authors would like to express their appreciation to the University of Cape Town for administrative support.

\section{Competing interests}

The authors declare that they have no financial or personal relationships that may have inappropriately influenced them in writing this article.

\section{Authors' contributions}

M.H. conceived of and performed the original study under the supervision of S.P. R.M. and M.Z. performed further research to update and expand the study. S.P., R.M. and M.Z. wrote the manuscript.

\section{Ethical considerations}

This article followed all ethical standards for research without direct contact with human or animal subjects.

\section{Funding Information}

This research received no specific grant from any funding agency in the public, commercial or not-for-profit sectors.

\section{Data availability}

Data sharing is not applicable to this article as no new data were created or analysed in this study.

\section{Disclaimer}

The views and opinions expressed in this article are those of the authors and do not necessarily reflect the official policy or position of any affiliated agency of the authors.

\section{References}

Abboud, L. \& Wagstaff, J., 2015, 'Legal troubles, market realities threaten Uber's global push', Reuters, viewed 31 May 2021, from https://www.reuters.com/ article/us-uber-global-insight-idUSKCNORZOA220151005.

Bales, R.A. \& Woo, C.P., 2016, 'The Uber million dollar question: Are Uber drivers employees or independent contractors', Mercer Law Review 68, viewed 24 August 2021, from https://heinonline.org/HOL/Page?handle=hein.journals/ mercer68\&id $=477 \&$ div $=\&$ collection $=$.

Barbara Berwick vs. Uber Technologies, Inc., No. 11-46739 EK, 2015, viewed 04 June 2021, from https://digitalcommons.law.scu.edu/cgi/viewcontent. cgi?article $=1988 \&$ context $=$ historical.

Basic Conditions of Employment Act, No. 75 of 1997, viewed 04 June 2021, from https://www.gov.za/sites/default/files/gcis_document/201409/a75-97.pdf.

Brown, G.E., 2016, 'An Uberdilemma : Employees and independent contractors in the sharing economy', University of Maryland Law Review 75, 15-43, viewed 25 August 2021, from https://heinonline.org/HOL/P?h=hein.journals/ endnot75\& $\mathrm{i}=15$.

Bruce, C., 2019, Labour regulation in the on-demand economy: An 'Uberfication' of the status quo?, University of Cape Town, viewed 31 May 2021, from https:// open.uct.ac.za/bitstream/handle/11427/31222/thesis_law_2019_bruce_caitlin. pdf? sequence=1\&isAllowed $=y$.

Darrin E. McGillis, v. Department of Economic Opportunity; and Rasier LLC, No. 3D15 2758, 2017 WL 438423, 2017, viewed 11 June 2021, from https://caselaw. findlaw.com/fl-district-court-of-appeal/1775972.html.

Department for Professional Employees, 2016, The misclassification of employees as independent contractors, viewed 25 August 2021, from https://www.dpeaflcio. org/factsheets/misclassification-of-employees-as-independent-contractors.

Dube, S.C., 2015, Uber: A game-changer in passenger transport in South Africa? CCRED Quarterly Review, viewed 31 May 2021, from https://www.competition. org.za/ccred-blog-competition-review/2015/11/22/uber-a-game-changer-inpassenger-transport-in-south-africa?rq=Shingie Chisoro Dube.

Edelman, B.G. \& Geradin, D., 2015, 'Efficiencies and regulatory shortcuts: How should we regulate companies like Airbnb and Uber', Stanford Technology Law Review 19, viewed 25 August 2021, from https://heinonline.org/HOL/Page?handle=hein journals/stant|r19\&id=309\&div=15\&collection=journals.

Efrati, A., 2019, 'Uber costs could rise by $20 \%$ if drivers were employees', The Information, viewed 31 May 2021, from https://www.theinformation.com/ articles/uber-costs-could-rise-by-20-if-drivers-were-employees?shared=adb0a1f 6235b6296.

Goodin, M.A. \& Shaw, S., 2017, 'Taxi drivers: Employees or independent contractors?', HR Daily Advisor, viewed 27 May 2021, from https://hrdailyadvisor.blr. com/2017/12/12/taxi-drivers-employees-independent-contractors/.

Hall-Geisler, K., 2014, '5 ways Uber is really different from a regular tax', HowStuffWorks, viewed 27 May 2021, from https://auto.howstuffworks.com/ tech-transport/5-ways-uber-really-different-from-regular-taxi.htm.

Hasner, S., 2019, 'One reason why Uber is fighting to classify drivers as contractors', Best Lawyers, viewed 31 May 2021, from https://www.bestlawyers.com/article/ why-uber-wants-drivers-as-contractors/2718.

Hawkins, A.J., 2019, 'Uber settles driver classification lawsuit for \$20 million', The Verge viewed 04 June 2021, from https://www.theverge.com/2019/3/12/18261755/ uber-driver-classification-lawsuit-settlement-20-million.

Helling, B., 2021, 'Uber fees: How much does Uber take from each ride? (with case studies)', Ridester, viewed 31 May 2021, from https://www.ridester.com/uberfees/.

Henderson, R., 2020, 'How COVID-19 has transformed the gig economy', Forbes, viewed 27 May 2021 , from https://www.forbes.com/sites/rebeccahenderson/2020/12/10/ how-covid-19-has-transformed-the-gig-economy/?sh=5c3536fb6c99

Hutchinson, T., 2015, 'The Doctrinal method: Incorporating interdisciplinary methods in reforming the law', Erasmus Law Review 8(3), 130-138. https://doi. org/10.5553/ELR.000055

Hutchinson, T. \& Duncan, N., 2012, 'Defining and describing what we do: Doctrina legal research', Deakin Law Review 17(1), 83-119, viewed 14 June 2018, from https://heinonline.org/HOL/Page?handle=hein.journals/deakin17\&id $=91 \&$ div $=8 \&$ collection=journals

Income Tax Act, Pub. L. No. 58 (1962), viewed 31 May 2021, from http://sars. mylexisnexis.co.za.

Internal Revenue Service, 2021a, Financial control, viewed 31 May 2021, from https:// www.irs.gov/businesses/small-businesses-self-employed/financial-control.

Internal Revenue Service, 2021b, Type of relationship, viewed 31 May 2021, from https://www.irs.gov/businesses/small-businesses-self-employed/type-ofrelationship.

Internal Revenue Service, 2021c, Behavioral control, viewed 31 May 2021, from https://www.irs.gov/businesses/small-businesses-self-employed/behavioralcontrol.

Internal Revenue Service, 2021d, Employer's supplemental tax quide, viewed 04 June 2021, from https://www.irs.gov/pub/irs-pdf/p15a.pdf

Internal Revenue Service, 2021e, Independent contractor (self-employed) or employee? viewed 31 May 2021, from https://www.irs.gov/businesses/smallbusinesses-self-employed/independent-contractor-self-employed-or-employee.

Iqbal, M., 2021, 'Uber revenue and usage statistics (2021)', Business of Apps, viewed 31 May 2021, from https://www.businessofapps.com/data/uber-statistics/\#7.

KPMG in Saudi Arabia, 2020, COVID-19 as accelerator for digital transformation and the rise of the gig economy, viewed 27 May 2021, from https://assets.kpmg/ content $/ \mathrm{dam} / \mathrm{kpmg} / \mathrm{sa} / \mathrm{pdf} / 2020 /$ covid-19-as-accelerator-of-digitaltransformation-and-the-gig-economy.pdf. 
Levin, S., 2016, 'Uber lawsuits timeline: Company ordered to pay out $\$ 161.9 \mathrm{~m}$ since 2009', The Guardian, viewed 31 May 2021, from https://www.theguardian.com/ technology/2016/apr/13/uber-lawsuits-619-million-ride-hailing-app.

Liss-Riordan, S. \& Pagano, A., 2015, Breaking news - Uber will pay \$100 million to settle independent contractor misclassification claims in California and Massachusetts, viewed 07 June 2021, from http://www.llrlaw.com/wp-content/uploads/2016/04/ viewe- 07 Juss-Uber-will-pay-100-million-to-settle-independent-contractormisclassification-claims.pdf.

Manyika, J., Lund, S., Bughin, J., Robinson, K., Mischke, J. \& Mahajan, D., 2016, Independent work: Choice, necessity, and the gig economy, viewed 23 August 2021, from https://www.mckinsey.com/featured-insights/employment-andgrowth/independent-work-choice-necessity-and-the-gig-economy\#.

Marshall, A., 2019, 'Why Uber thinks it can still call its drivers contractors', Wired, viewed 31 May 2021, from https://www.wired.com/story/why-uber-still-calldrivers-contractors/.

MBO Partners, 2019, The State of Independence in America 2019, viewed 27 May 2021, from https://www.mbopartners.com/state-of-independence/mbopartners-state-of-independence-in-america-2019/.

McCabe, E.E., 2016, 'Not like the others: Applying the Fair Labor Standards Act to the sharing economy', University of Kansas Law Review 65, viewed 24 August 2021 from https://heinonline.org/HOL/Page?handle=hein.journals/ukalr65\&id= $161 \&$ div $=8 \&$ collection=journals

McKerchar, M., 2008, 'Philosophical paradigms, inquiry strategies and knowledge claims: Applying the principles of research design and conduct to taxation EJournal of Tax Research 6(1), 5-22, viewed 02 January 2019, from http://www. austlii.edu.au/au/journals/eJITaxR/2008/1.html.

Means, B. \& Seiner, J.A., 2015, 'Navigating the Uber economy', U.C. Davis Law Review 49(4), 1511-1546, viewed 25 August 2021, from https://heinonline.org/HOL/ Page?handle=hein.journals/davlr49\&id=1531\&div=39\&collection=journals.

Muller, K., 2020, Distinguishing between independent contractors and employees, South African Institute of Taxation, viewed 31 May 2021, from https://www. thesait.org.za/news/524979/Distinguishing-between-Independent-Contractorsthesait.org.za/news/

Murray, J., 2021, 'All the types of employment taxes', The Balance Small Business, viewed 27 May 2021, from https://www.thebalancesmb.com/all-the-types-ofemployment-taxes-397961.

National Minimum Wage Act, No. 9 of 2018, viewed from https://www.gov.za/sites/ default/files/gcis document/201811/42060gon1303act9of2018.pdf.

Naughton, J., 2021, 'Uber's UK supreme court defeat should mean big changes to the gig economy', The Guardian, viewed 31 May 2021, from https://www.theguardian. com/commentisfree/2021/feb/27/ubers-uk-supreme-court-defeat-should-meanbig-changes-to-the-gig-economy.

Nickolas, S., 2021, 'Variable cost vs. fixed cost: What's the difference?', Investopedia viewed 31 May 2021, from https://www.investopedia.com/ask/answers/032515/ what-difference-between-variable-cost-and-fixed-cost-economics.asp.

Pepić, L., 2018, 'The sharing economy: Uber and its effect on taxi companies', Acto Economica 16(28), 123-136, viewed 31 May 2021, https://doi.org/10.7251/ ace1828123p
Rasier, LLC v. Florida Department of Economic Opportunity, No. 00262834 68-02, 2015, viewed 11 June 2021, from https://www.manatt.com/uploadedFiles/Content/4 News and Events/Newsletters/EmploymentLaw@manatt/FloridaDeptofEconomic OpportunityUberopinion.pdf.

Reis, A. \& Chand, V., 2020, 'Uber drivers: Employees or independent contractors?', Kluwer International Tax Blog, viewed 27 May 2021, from http://kluwertaxblog. com/2020/04/03/uber-drivers-employees-or-independent-contractors/.

Sondermann Capizzi, C., 2019, 'What does the Uber Independent contractor settlement mean for businesses operating in the gig economy?', McMahon Berger, viewed 31 May 2021, from https://www.mcmahonberger.com/news/ what-does-the-uber-independent-contractor-settlement-mean-for-businessesoperating-in-the-gig-economy/.

South African Revenue Service, 2019, Interpretation note 17 (Issue 5), viewed 31 May 2021, from https://www.sars.gov.za/wp-content/uploads/Legal/Notes/LAPDIntR-IN-2012-17-Employees-Tax-Independent-Contractors.pdf.

Taekema, S., 2018, 'Theoretical and normative frameworks for legal research: Putting theory into practice', Law and Method 1-17, viewed 13 September 2019, https://doi.org/10.5553/REM/.000031

Unemployment Insurance Act, No. 63 of 2001, viewed 04 June 2021, from https:// www.gov.za/sites/default/files/gcis_document/201409/a63-010.pdf.

U.S. Department of Labor, 2008, Fact sheet 13: Employment relationship under the Fair Labor Standards Act (FLSA), U.S. Department of Labor, viewed 31 May 2021, from https://www.dol.gov/agencies/whd/fact-sheets/13-flsa-employment-relationship.

U.S. Department of Labor, 2021, Wages and the Fair Labor Standards Act, U.S. Department of Labor, viewed 04 June 2021, from https://www.dol.gov/agencies/whd/flsa.

U.S. Department of Labor, 2019, Unemployment compensation, viewed 04 June 2021, https://oui.doleta.gov/unemploy/pdf/partnership.pdf.

Uber, 2021a, 'Can I share my account with friends?', Uber Help, viewed 31 May 2021, from https://help.uber.com/driving-and-delivering/article/can-i-share-myaccount-with-friends? nodeld=bd0db839-294e-4109-bf7f-e70722d5c876.

Uber, 2021b, 'How does Uber work?', Uber Help, viewed 04 June 2021, from https:// help.uber.com/riders/article/how-does-uber-work?nodeld=738d1ff7-5fe0-4383b34c-4a2480efd71e.

Uber, 2021c, 'The basics: How to drive with Uber in South Africa', Uber, viewed 31 May 2021, from https://www.uber.com/za/en/drive/requirements/.

Wilson, C., 2013, 'Taxi! Uber lands in SA', Tech Central, viewed 29 April 2021, from http://www.techcentral.co.za/taxi-uber-lands-in-sa/42646/.

Wong, S., 2021, Market share of the leading ride-hailing companies in the United States from September 2017 to March 2021, Statista, viewed 04 June 2021, from https://www.statista.com/statistics/910704/market-share-of-ridesharecompanies-united-states/.

Worker status: Employees and independent contractors, Assembly bill, No. 5 of 2019, viewed from https://leginfo.legislature.ca.gov/faces/billTextClient.xhtml?bill_ id=201920200AB5.

World Bank Group, 2019, 'Why it matters', Paying Taxes, viewed 27 May 2021, from https://www.doingbusiness.org/en/data/exploretopics/paying-taxes/why-matters. 